ISSN 1392-3196 / e-ISSN 2335-8947

Zemdirbyste-Agriculture, vol. 102, No. 4 (2015), p. 437-442

DOI $10.13080 / \mathrm{z}-\mathrm{a} .2015 .102 .056$

\title{
Assessment of morpho-anatomical traits of red fescue (Festuca rubra L.) germplasm differing in origin
}

\author{
Vaclovas STUKONIS ${ }^{1}$, Sigitas JUZĖNAS ${ }^{2}$, Jurgita CESEVIČIENÉ ${ }^{1}$, Egle NORKEVIČIENÉ ${ }^{1}$ \\ ${ }^{1}$ Institute of Agriculture, Lithuanian Research Centre for Agriculture and Forestry \\ Instituto 1, Akademija, Kèdainiai distr., Lithuania \\ E-mail: vaclovas@1zi.lt \\ ${ }^{2}$ Vilnius University \\ M. K. Čiurlionio 21/27, Vilnius, Lithuania
}

\begin{abstract}
Thirty-eight accessions of red fescue (Festuca rubra L.), collected from different bioclimatic regions of Ukraine and Latvia, were evaluated for 16 quantitative traits in the Central Lowland of Lithuania. The research was aimed to evaluate morpho-anatomical traits of the populations and reveal the relationship with their geographic origin. The data collected indicated that F. rubra populations differing in origin were quite similar in their morphology. However, significant differences in length of lemma, flag and stem leaf laminas, number of leaf ribs, veins and sclerenchyma bundles were established between the Ukrainian and Latvian populations. Moreover, a greater variation of morpho-anatomical traits was noted for the populations from southern part of $F$. rubra distribution range. Principal component analysis enabled us to differentiate 7 most promising populations (of which 6 were from Ukraine) based on the most important pre-breeding traits such as seed number per plant and plant height.
\end{abstract}

Key words: ecotype, geographic origin, lawn, plant breeding, seed yield.

\section{Introduction}

The presence of a major lawn industry in Europe, North America and other regions promotes the accelerated usage of cool-season grasses (Bertin et al., 2009; Huyghe, 2010). From the economic viewpoint, the most suitable grass species are those that are well adapted to growing on infertile light-textured soils and dry habitats, tolerant of adverse environment and require minimal maintenance. The red fescue (Festuca rubra L.) meets all these requirements and belongs to a group of grasses that have reached greatest economic importance in the European Union and abroad (Altpeter, Xu, 2000). Red fescue is a perennial, rhizomatous, loosely to densely tufted cool-season grass distributed circumboreally and native to all provinces and territories of Europe, Asia, Canada, Mexico, Africa also New Zealand (Stancík, 2003). Traditionally, the species is widely used for establishment of lawns of minimal maintenance as well as for greening of dunes, coastal areas or roadsides and re-cultivation of damaged soils (Bertin et al., 2009). Because of the species tolerance to close grazing and good hay quality, it is also considered as a valuable forage grass (Stanisavljević et al., 2014).

The importance of $F$. rubra as a common lawntype grass used in Europe generated a need for better understanding of diversity of wild ecotypes of the species, because of the potential to use them in breeding programs. Naturally occurring grasses are characterised by a great diversity of forms with different morphological traits and biological characteristics. These wild or semi-natural genotypes are a very valuable gene pool, which may be used for improving important breeding characteristics (Lemežienè, Kanapeckas, 2008). Until recently, the cultivars of $F$. rubra have not been subjected to any plant improvement efforts and most of them have mostly been gathered from the direct selection for their biologically and economically important qualities (Tarakanovas, Kanapeckas, 2005; Lemežienè, Kanapeckas, 2008). Currently, crosses between inbred varieties and genetic improvement methods increased prospects for breeding new cultivars (Altpeter, Xu, 2000; Lemežiené, Kanapeckas, 2008). Most attempts in fescue breeding focused on measurement of resistance to leaf diseases, seed yield, and re-growth after cuts and other lawn forming abilities (Bonos et al., 2006; Rao, Rognli, 2014). Increasing demand for seeds from turf industry currently is driving to carry out breeding based on higher seed yield (Huyghe, 2010). The European Union database of registered plant varieties in 2014 included 347 registered cultivars of F. rubra. However, extensive use of closelyrelated cultivars by producers could result in vulnerability to pests and diseases. Moreover, several studies have shown that some cultivars have varied morphological and economically important traits depending on the origin of the genotype (Dabrowska, 2011). Alternatively, differences in morphometric traits among populations may be due to plastic responses to local environmental conditions (Guo et al., 2010). Climate change currently promotes a focus on settings experiencing variable 
environmental conditions and further study in regions with temperate climate is therefore suggested (Bertin et al., 2009). Obviously, the regional development of site-adapted genotypes is essential due to their diverse adaptation in a given latitude or geographical area.

The present study was set up to gain new insights into relationships of morpho-anatomical traits and geographic origin of the accessions of Festuca rubra in order to determine the source of useful variation. Such information could be helpful in identifying optimal breeding strategies for F. rubra improvement.

\section{Materials and methods}

The collection trials were carried out in the

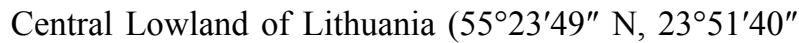
E), at the Institute of Agriculture, Lithuanian Research Centre for Agriculture and Forestry. The seeds were collected in August of 2008 from two wide geographic areas with very different ecological conditions: 16 from Ukraine (Northwest Ukraine, Western Pripyat river botanical-geographical region) and 22 from Latvia (Vidzeme, Riga and Zemgale regions). According to a statistically derived global environmental stratification
(Metzger et al., 2013), Latvia and Lithuania are in the same environmental zone - cold and mesic (G12). In contrast, seed samples from Ukraine were collected in a cool temperate and dry (H5) zone. Environmental zones differ mainly in the daily sum of annual degrees of temperature above $0^{\circ} \mathrm{C}$ and reflect well differences in plant growth periods (Metzger et al., 2013).

The seeds of red fescue (Festuca rubra L.) were collected from semi-natural mesic grasslands (EUNIS habitat type code E2), mainly from permanent mesotrophic pastures and aftermath-grazed meadows (E2.1) and mesic grassland that is not currently mown or used for pasture, excluding abandoned pastures (E2.13) (Davies et al., 2004). A list of the accessions with information related to the sites (country of origin, geographical coordinates (WGS84 datum) and elevation above sea level) is presented in Table 1. Later, the collected seeds were used to set up an experimental germplasm collection.

The germplasm collection was established in a field trial in the spring of 2011 using seedlings grown in a greenhouse. The collection was investigated in 20122013. Individual plants were spaced $0.5 \mathrm{~m}$ apart with 24 plants per population. The soil of the experimental site is Endocalcari-Epihypogleyic Cambisol (CMg-p-w-can)

Table 1. List of 38 Festuca rubra populations with indication of their geographical origin

\begin{tabular}{|c|c|c|c|c|c|}
\hline $\begin{array}{c}\text { Population } \\
\text { number }\end{array}$ & $\begin{array}{c}\text { Population } \\
\text { identification (PI) } \\
\text { number in collection }\end{array}$ & Origin & Latitude & Longitude & $\begin{array}{c}\text { Elevation } \\
\mathrm{m}\end{array}$ \\
\hline 1 & 638 & Ukraine & $50^{\circ} 39^{\prime} 59^{\prime \prime} \mathrm{N}$ & $28^{\circ} 38^{\prime} 02^{\prime \prime} \mathrm{E}$ & 193 \\
\hline 2 & 639 & Ukraine & $50^{\circ} 34^{\prime} 94^{\prime \prime} \mathrm{N}$ & $26^{\circ} 47^{\prime} 17^{\prime \prime} \mathrm{E}$ & 224 \\
\hline 3 & 640 & Ukraine & $50^{\circ} 48^{\prime} 07^{\prime \prime} \mathrm{N}$ & $27^{\circ} 57^{\prime} 38^{\prime \prime} \mathrm{E}$ & 177 \\
\hline 4 & 641 & Ukraine & $51^{\circ} 01^{\prime} 70^{\prime \prime} \mathrm{N}$ & $25^{\circ} 07^{\prime} 25^{\prime \prime} \mathrm{E}$ & 197 \\
\hline 5 & 642 & Ukraine & $50^{\circ} 36^{\prime} 08^{\prime \prime} \mathrm{N}$ & $26^{\circ} 32^{\prime} 24^{\prime \prime} \mathrm{E}$ & 187 \\
\hline 6 & 643 & Ukraine & $50^{\circ} 20^{\prime} 49^{\prime \prime} \mathrm{N}$ & $28^{\circ} 20^{\prime} 33^{\prime \prime} \mathrm{E}$ & 219 \\
\hline 7 & 644 & Ukraine & $50^{\circ} 26^{\prime} 94^{\prime \prime} \mathrm{N}$ & $28^{\circ} 05^{\prime} 17^{\prime \prime} \mathrm{E}$ & 220 \\
\hline 8 & 645 & Ukraine & $50^{\circ} 34^{\prime} 29^{\prime \prime} \mathrm{N}$ & $27^{\circ} 12^{\prime} 22^{\prime \prime} \mathrm{E}$ & 230 \\
\hline 9 & 646 & Ukraine & $50^{\circ} 27^{\prime} 99^{\prime \prime} \mathrm{N}$ & $25^{\circ} 50^{\prime} 69^{\prime \prime} \mathrm{E}$ & 238 \\
\hline 10 & $646-2$ & Ukraine & $50^{\circ} 27^{\prime} 99^{\prime \prime} \mathrm{N}$ & $25^{\circ} 50^{\prime} 69^{\prime \prime} \mathrm{E}$ & 238 \\
\hline 11 & 647 & Ukraine & $50^{\circ} 43^{\prime} 82^{\prime \prime} \mathrm{N}$ & $28^{\circ} 37^{\prime} 26^{\prime \prime} \mathrm{E}$ & 182 \\
\hline 12 & 648 & Ukraine & $50^{\circ} 33^{\prime} 95^{\prime \prime} \mathrm{N}$ & $27^{\circ} 42^{\prime} 78^{\prime \prime} \mathrm{E}$ & 191 \\
\hline 13 & 649 & Ukraine & $50^{\circ} 16^{\prime} 71^{\prime \prime} \mathrm{N}$ & $28^{\circ} 31^{\prime} 56^{\prime \prime} \mathrm{E}$ & 191 \\
\hline 14 & 650 & Ukraine & $50^{\circ} 44^{\prime} 00^{\prime \prime} \mathrm{N}$ & $28^{\circ} 37^{\prime} 33^{\prime \prime} \mathrm{E}$ & 182 \\
\hline 15 & 651 & Ukraine & $50^{\circ} 11^{\prime} 21^{\prime \prime} \mathrm{N}$ & $25^{\circ} 24^{\prime} 94^{\prime \prime} \mathrm{E}$ & 218 \\
\hline 16 & 652 & Ukraine & $50^{\circ} 20^{\prime} 09^{\prime \prime} \mathrm{N}$ & $25^{\circ} 38^{\prime} 49^{\prime \prime} \mathrm{E}$ & 197 \\
\hline 17 & 614 & Latvia & $55^{\circ} 55^{\prime} 01^{\prime \prime} \mathrm{N}$ & $26^{\circ} 53^{\prime} 60^{\prime \prime} \mathrm{E}$ & 93 \\
\hline 18 & 615 & Latvia & $56^{\circ} 27^{\prime} 24^{\prime \prime} \mathrm{N}$ & $27^{\circ} 22^{\prime} 95^{\prime \prime} \mathrm{E}$ & 151 \\
\hline 19 & 616 & Latvia & $55^{\circ} 54^{\prime} 68^{\prime \prime} \mathrm{N}$ & $26^{\circ} 43^{\prime} 54^{\prime \prime} \mathrm{E}$ & 74 \\
\hline 20 & 617 & Latvia & $56^{\circ} 18^{\prime} 88^{\prime \prime} \mathrm{N}$ & $27^{\circ} 30^{\prime} 91^{\prime \prime} \mathrm{E}$ & 165 \\
\hline 21 & $617-2$ & Latvia & $56^{\circ} 18^{\prime} 88^{\prime \prime} \mathrm{N}$ & $27^{\circ} 30^{\prime} 91^{\prime \prime} \mathrm{E}$ & 165 \\
\hline 22 & 618 & Latvia & $56^{\circ} 01^{\prime} 30^{\prime \prime} \mathrm{N}$ & $25^{\circ} 54^{\prime} 96^{\prime \prime} \mathrm{E}$ & 80 \\
\hline 23 & 619 & Latvia & $56^{\circ} 15^{\prime} 56^{\prime \prime} \mathrm{N}$ & $25^{\circ} 31^{\prime} 88^{\prime \prime} \mathrm{E}$ & 144 \\
\hline 24 & 621 & Latvia & $56^{\circ} 58^{\prime} 93^{\prime \prime} \mathrm{N}$ & $27^{\circ} 29^{\prime} 71^{\prime \prime} \mathrm{E}$ & 152 \\
\hline 25 & 622 & Latvia & $56^{\circ} 16^{\prime} 19^{\prime \prime} \mathrm{N}$ & $25^{\circ} 25^{\prime} 47^{\prime \prime} \mathrm{E}$ & 146 \\
\hline 26 & 623 & Latvia & $56^{\circ} 34^{\prime} 97^{\prime \prime} \mathrm{N}$ & $27^{\circ} 14^{\prime} 95^{\prime \prime} \mathrm{E}$ & 153 \\
\hline 27 & 624 & Latvia & $56^{\circ} 09^{\prime} 03^{\prime \prime} \mathrm{N}$ & $27^{\circ} 38^{\prime} 41^{\prime \prime} \mathrm{E}$ & 171 \\
\hline 28 & 625 & Latvia & $56^{\circ} 15^{\prime} 44^{\prime \prime} \mathrm{N}$ & $26^{\circ} 26^{\prime} 46^{\prime \prime} \mathrm{E}$ & 121 \\
\hline 29 & 626 & Latvia & $55^{\circ} 59^{\prime} 62^{\prime \prime} \mathrm{N}$ & $27^{\circ} 15^{\prime} 42^{\prime \prime} \mathrm{E}$ & 142 \\
\hline 30 & 627 & Latvia & $56^{\circ} 47^{\prime} 84^{\prime \prime} \mathrm{N}$ & $26^{\circ} 56^{\prime} 04^{\prime \prime} \mathrm{E}$ & 93 \\
\hline 31 & 629 & Latvia & $56^{\circ} 38^{\prime} 62^{\prime \prime} \mathrm{N}$ & $26^{\circ} 05^{\prime} 70^{\prime \prime} \mathrm{E}$ & 121 \\
\hline 32 & 631 & Latvia & $56^{\circ} 05^{\prime} 01^{\prime \prime} \mathrm{N}$ & $27^{\circ} 06^{\prime} 63^{\prime \prime} \mathrm{E}$ & 172 \\
\hline 33 & 632 & Latvia & $56^{\circ} 49^{\prime} 94^{\prime \prime} \mathrm{N}$ & $26^{\circ} 30^{\prime} 85^{\prime \prime} \mathrm{E}$ & 91 \\
\hline 34 & $632-2$ & Latvia & $56^{\circ} 49^{\prime} 94^{\prime \prime} \mathrm{N}$ & $26^{\circ} 30^{\prime} 85^{\prime \prime} \mathrm{E}$ & 91 \\
\hline 35 & 633 & Latvia & $56^{\circ} 07^{\prime} 73^{\prime \prime} \mathrm{N}$ & $27^{\circ} 04^{\prime} 05^{\prime \prime} \mathrm{E}$ & 148 \\
\hline 36 & 634 & Latvia & $56^{\circ} 07^{\prime} 95^{\prime \prime} \mathrm{N}$ & $27^{\circ} 18^{\prime} 37^{\prime \prime} \mathrm{E}$ & 163 \\
\hline 37 & 636 & Latvia & $55^{\circ} 52^{\prime} 68^{\prime \prime} \mathrm{N}$ & $27^{\circ} 07^{\prime} 64^{\prime \prime} \mathrm{E}$ & 94 \\
\hline 38 & 637 & Latvia & $55^{\circ} 52^{\prime} 68^{\prime \prime} \mathrm{N}$ & $27^{\circ} 07^{\prime} 64^{\prime \prime} \mathrm{E}$ & 290 \\
\hline
\end{tabular}


with the following characteristics of a plough layer ( 0 $25 \mathrm{~cm}): \mathrm{pH}_{\mathrm{KCl}} 6.5-7.0,2.5-4.0 \%$ of humus, $50-80 \mathrm{mg} \mathrm{kg}^{-1}$ of available phosphorus $\left(\mathrm{P}_{2} \mathrm{O}_{5}\right)$ and $100-150 \mathrm{mg} \mathrm{kg}^{-1}$ of available potassium $\left(\mathrm{K}_{2} \mathrm{O}\right)$. Fertilizer at a rate of $\mathrm{N}_{60} \mathrm{P}_{60} \mathrm{~K}_{60}$ was applied pre-planting once and $\mathrm{N}_{60}$ was applied in spring of the following year. Chemical plant protection was not used.

The plants of the second year of growing (2012) were studied for taxonomically important morphoanatomical characteristics. For each genotype, five plants per population were herbarized at a stage of full flowering and detailed measurements were taken from five single tillers, inflorescences and spikelets. The following traits were assessed and analysed in the laboratory: plant height $(\mathrm{cm})$, length of panicle $(\mathrm{cm})$, length of flag and stem leaf lamina $(\mathrm{cm})$, spikelet $(\mathrm{mm})$, upper and lower glume $(\mathrm{mm})$, lemma $(\mathrm{mm})$, awn $(\mathrm{mm})$ and number of flowers per spikelet. Plant height was recorded as the height of the tallest tiller of each plant measured from base of the plant to the top of the uppermost spikelet on the panicle, excluding awn. Length of panicle measured from the base of the lowest spikelet to the tip of the uppermost spikelet on the panicle, excluding awn. The length of flag and stem leaf lamina was measured from the leaf base to the leaf tip of the fully expanded leaves. The length of spikelet, upper and lower glume, lemma and awn was measured using binocular microscope LOMO MBS-9 fitted with a 0.1-10 $\mathrm{mm}$ micrometer. The number of flowers was counted as the total number of spikelets in the sampled panicles. For anatomical leaf analyses, the stem leaves were taken from herbarium and cross-sectioned. The width (diameter) of lamina ( $\mathrm{mm}$ ) was measured and sclerenchyma bundles, veins and ribs of internal leaf surface were counted. At seed maturity stage, 16 randomly selected plants per population were sampled to evaluate seed number per plant and 1000 seed weight (g).

Statistical analysis was carried out in PAST $2.17 c$ (Hammer et al., 2001). Before analysis, all data of morpho-anatomical characteristics were tested for normality (Shapiro-Wilk test, $P \geq 0.05$ ). To meet the assumptions of normality, the numbers of sclerenchyma bundles, veins and ribs were log-transformed using the base-10 logarithm. The means were compared by $t$-test; Welch test was used in the cases of heteroscedasticity in data $(F$ test, $P<0.05)$. Multidimensional variation among the morpho-anatomical traits of $F$. rubra populations grown in the collection was summarized using principal component analysis (PCA). All principal components were derived using correlation matrices based on population-means. The plot and the curve of eigenvalues, expected under a random model, indicated the number of significant components (Jackson, 1993).

\section{Results and discussion}

In the current study, the $F$. rubra germplasm collection accessions originated from Latvia and Ukraine exhibited similar diversity for the better part of morphoanatomical traits. The mean, standard error, variance and range of each morpho-anatomical descriptor are shown in Table 2.

Table 2. Morpho-anatomical characteristics of 38 accessions of Festuca rubra germplasm collection originated from Latvia and Ukraine

\begin{tabular}{|c|c|c|c|c|c|c|}
\hline $\begin{array}{l}\text { Morpho-anatomical } \\
\text { descriptor }\end{array}$ & Origin & Mean $\pm \mathrm{SE}$ & Min & Max & $\mathrm{CV} \%$ & $\begin{array}{c}\text { Ukraine } v s \text { Latvia } \\
P \text {-value* }\end{array}$ \\
\hline Plant height $\mathrm{cm}$ & $\begin{array}{l}\text { Ukraine } \\
\text { Latvia }\end{array}$ & $\begin{array}{c}100.57 \pm 2.24 \\
99.81 \pm 0.99\end{array}$ & $\begin{array}{l}87.6 \\
92.0\end{array}$ & $\begin{array}{l}118.8 \\
108.0\end{array}$ & $\begin{array}{l}8.89 \\
4.63\end{array}$ & $0.760^{\mathrm{b}}$ \\
\hline Width of leaf lamina mm & $\begin{array}{l}\text { Ukraine } \\
\text { Latvia }\end{array}$ & $\begin{array}{l}1.03 \pm 0.02 \\
1.11 \pm 0.03\end{array}$ & $\begin{array}{l}0.88 \\
0.80\end{array}$ & $\begin{array}{l}1.23 \\
1.32 \\
\end{array}$ & $\begin{array}{c}8.81 \\
12.60\end{array}$ & $0.080^{\mathrm{a}}$ \\
\hline Length of flag leaf lamina $\mathrm{cm}$ & $\begin{array}{c}\text { Ukraine } \\
\text { Latvia }\end{array}$ & $\begin{array}{l}12.04 \pm 0.35 \\
10.50 \pm 0.37 \\
\end{array}$ & $\begin{array}{l}9.13 \\
7.10 \\
\end{array}$ & $\begin{array}{l}13.95 \\
14.32 \\
\end{array}$ & $\begin{array}{l}11.59 \\
16.66 \\
\end{array}$ & $\mathbf{0 . 0 0 6}^{\mathrm{a}}$ \\
\hline Length of stem leaf lamina $\mathrm{cm}$ & $\begin{array}{l}\text { Ukraine } \\
\text { Latvia }\end{array}$ & $\begin{array}{l}11.19 \pm 0.41 \\
10.12 \pm 0.31\end{array}$ & $\begin{array}{l}8.45 \\
7.40 \\
\end{array}$ & $\begin{array}{l}14.00 \\
13.10\end{array}$ & $\begin{array}{l}14.77 \\
14.42\end{array}$ & $\mathbf{0 . 0 4 3}^{\mathrm{a}}$ \\
\hline Length of panicle $\mathrm{cm}$ & $\begin{array}{l}\text { Ukraine } \\
\text { Latvia }\end{array}$ & $\begin{array}{l}15.78 \pm 0.43 \\
15.29 \pm 0.29 \\
\end{array}$ & $\begin{array}{l}13.35 \\
13.03 \\
\end{array}$ & $\begin{array}{l}19.80 \\
17.73 \\
\end{array}$ & $\begin{array}{l}10.83 \\
8.95\end{array}$ & $0.328^{\mathrm{a}}$ \\
\hline Length of spikelet $\mathrm{mm}$ & $\begin{array}{l}\text { Ukraine } \\
\text { Latvia }\end{array}$ & $\begin{array}{l}11.10 \pm 0.27 \\
11.03 \pm 0.18\end{array}$ & $\begin{array}{l}9.42 \\
9.33\end{array}$ & $\begin{array}{l}12.98 \\
12.42\end{array}$ & $\begin{array}{l}9.82 \\
7.57\end{array}$ & $0.817^{\mathrm{a}}$ \\
\hline Length of lower glume $\mathrm{mm}$ & $\begin{array}{l}\text { Ukraine } \\
\text { Latvia }\end{array}$ & $\begin{array}{l}4.85 \pm 0.15 \\
4.81 \pm 0.08\end{array}$ & $\begin{array}{l}3.83 \\
4.30 \\
\end{array}$ & $\begin{array}{l}6.33 \\
5.43 \\
\end{array}$ & $\begin{array}{l}12.51 \\
7.35\end{array}$ & $0.815^{\mathrm{b}}$ \\
\hline Length of upper glume mm & $\begin{array}{c}\text { Ukraine } \\
\text { Latvia }\end{array}$ & $\begin{array}{l}3.46 \pm 0.13 \\
3.31 \pm 0.07\end{array}$ & $\begin{array}{l}2.53 \\
2.76\end{array}$ & $\begin{array}{l}4.88 \\
3.90 \\
\end{array}$ & $\begin{array}{l}15.59 \\
9.56\end{array}$ & $0.334^{\mathrm{b}}$ \\
\hline Length of lemma mm & $\begin{array}{l}\text { Ukraine } \\
\text { Latvia }\end{array}$ & $\begin{array}{l}6.47 \pm 0.13 \\
6.09 \pm 0.06\end{array}$ & $\begin{array}{l}5.68 \\
5.65\end{array}$ & $\begin{array}{l}7.88 \\
6.78 \\
\end{array}$ & $\begin{array}{l}7.74 \\
4.84 \\
\end{array}$ & $\mathbf{0 . 0 1 3}^{\mathrm{b}}$ \\
\hline Length of awn mm & $\begin{array}{l}\text { Ukraine } \\
\text { Latvia }\end{array}$ & $\begin{array}{l}1.58 \pm 0.08 \\
1.57 \pm 0.07\end{array}$ & $\begin{array}{l}0.90 \\
1.02\end{array}$ & $\begin{array}{l}2.10 \\
2.44\end{array}$ & $\begin{array}{l}21.03 \\
22.16\end{array}$ & $0.988^{\mathrm{a}}$ \\
\hline Number of flowers per spikelet & $\begin{array}{c}\text { Ukraine } \\
\text { Latvia }\end{array}$ & $\begin{array}{l}5.39 \pm 0.16 \\
5.25 \pm 0.16\end{array}$ & $\begin{array}{l}4.20 \\
3.40 \\
\end{array}$ & $\begin{array}{l}6.25 \\
6.50 \\
\end{array}$ & $\begin{array}{l}11.97 \\
14.00 \\
\end{array}$ & $0.557^{\mathrm{a}}$ \\
\hline Number of ribs & $\begin{array}{l}\text { Ukraine } \\
\text { Latvia }\end{array}$ & $\begin{array}{l}6.10 \pm 0.21 \\
6.99 \pm 0.18\end{array}$ & $\begin{array}{l}5.25 \\
5.25\end{array}$ & $\begin{array}{l}8.50 \\
8.25\end{array}$ & $\begin{array}{l}13.79 \\
11.95\end{array}$ & $\mathbf{0 . 0 0 2}^{\mathrm{a}}$ \\
\hline Number of veins & $\begin{array}{c}\text { Ukraine } \\
\text { Latvia }\end{array}$ & $\begin{array}{l}7.36 \pm 0.19 \\
7.86 \pm 0.13\end{array}$ & $\begin{array}{l}6.25 \\
6.50 \\
\end{array}$ & $\begin{array}{l}9.50 \\
9.00\end{array}$ & $\begin{array}{l}10.32 \\
7.84\end{array}$ & $0.026^{\mathrm{a}}$ \\
\hline Number of sclerenchyma bundles & $\begin{array}{l}\text { Ukraine } \\
\text { Latvia }\end{array}$ & $\begin{array}{l}8.91 \pm 0.20 \\
9.54 \pm 0.17\end{array}$ & $\begin{array}{l}8.00 \\
7.50 \\
\end{array}$ & $\begin{array}{l}11.25 \\
11.00\end{array}$ & $\begin{array}{l}9.15 \\
8.36 \\
\end{array}$ & $\mathbf{0 . 0 2 2}^{\mathrm{a}}$ \\
\hline Number of seeds per plant & $\begin{array}{c}\text { Ukraine } \\
\text { Latvia }\end{array}$ & $\begin{array}{l}292.8 \pm 13.6 \\
248.8 \pm 16.6\end{array}$ & $\begin{array}{l}140.1 \\
67.8\end{array}$ & $\begin{array}{l}370.8 \\
356.7\end{array}$ & $\begin{array}{l}18.6 \\
31.3\end{array}$ & $0.060^{\mathrm{a}}$ \\
\hline 1000 seed weight $g$ & $\begin{array}{l}\text { Ukraine } \\
\text { Latvia }\end{array}$ & $\begin{array}{l}1.33 \pm 0.02 \\
1.33 \pm 0.03\end{array}$ & $\begin{array}{l}07.0 \\
0.97\end{array}$ & $\begin{array}{l}1.43 \\
1.58\end{array}$ & $\begin{array}{c}5.70 \\
10.81\end{array}$ & $0.872^{\mathrm{b}}$ \\
\hline
\end{tabular}

Note. ${ }^{\text {a }}-t$-test, ${ }^{\mathrm{b}}$ - Welch test; ${ }^{*}$ - bold text indicates significant difference of means (Ukraine $v s$ Latvia); SE - standard error; CV - coefficient of variation at $P<0.05$. 
Significant differences among the Ukrainian and Latvian populations were observed for length of flag and stem leaf laminas, length of lemmas, likewise anatomical leaf characters $(P<0.05)$. The populations native to Ukraine had longer leaves indicating their high breeding value for forage traits. To support this hypothesis, we could examine the findings of Kanapeckas et al. (2010) who tested germplasm of genus Festuca collected from natural habitats in the west of Ukraine. They reported that all ecotypes of $F$. rubra were forage-type according to the morphological features. With regard to seed productivity characteristics, our study found that Ukrainian populations formed a little more flowers per plant and more seeds than Latvian populations and these agronomically important traits showed less variation in Ukrainian populations. However, these differences were not substantial and statistically significant. It is interesting to note that the average weight of 1000 seeds in both groups was the same. This finding supports the idea that within species seed mass is a remarkably constant characteristic ( $\mathrm{Bu}$ et al., 2007). It is also noteworthy that Ukrainian populations of $F$. rubra had significantly longer lemmas $(P<0.05)$ than Latvian ones. The study of Ma et al. (2008) who worked with Leymus chinensis (Trin.) clearly showed that lemma plays the main role in the dormancy of seeds and offers great mechanical resistance to the small embryo. Increase in this seed covering structure may reflect adaptation of Ukrainian F. rubra populations to longer plant growth periods.

PCA extracted most informative first four principal components which explained $69.3 \%$ of the variance in the collection data (Table 3 ). The relationships between PC1 and variables can be interpreted as plant size, in general. Nevertheless, the negative correlation between PC1 and leaf diameter and PC1 and anatomical features of lamina suggests that PC1 shows phenotypic variation, inferred by peinomorphy inducing factors. PC2 positively associated with size of plant flowering system. Both of first two components must be taken into consideration when assessing lawn or forage (small or higher) type plant potential.

Table 3. Correlations between first four principal components and 16 morpho-anatomical traits of Festuca rubra grown in the collection

\begin{tabular}{lcccc}
\hline \multicolumn{1}{c}{ Morpho-anatomical traits } & PC1 & PC2 & PC3 & PC4 \\
\hline \multicolumn{1}{c}{ Percentages of variance explained } & $24.34 \%$ & $19.15 \%$ & $15.16 \%$ & $10.65 \%$ \\
\hline Plant height & 0.39 & 0.33 & 0.28 & 0.01 \\
Width of leaf lamina & $-\mathbf{0 . 4 5}$ & $\mathbf{0 . 4 5}$ & -0.02 & $\mathbf{0 . 4 6}$ \\
Length of flag leaf lamina & $\mathbf{0 . 6 9}$ & -0.10 & 0.38 & $\mathbf{0 . 4 0}$ \\
Length of stem leaf lamina & $\mathbf{0 . 5 8}$ & -0.28 & 0.24 & 0.36 \\
Lengths of panicle & $\mathbf{0 . 5 7}$ & $\mathbf{0 . 4 3}$ & $\mathbf{0 . 4 2}$ & 0.04 \\
Lengths of spikelet & 0.15 & $\mathbf{0 . 7 4}$ & -0.34 & 0.26 \\
Lengths of lower glume & $\mathbf{0 . 5 5}$ & $\mathbf{0 . 5 6}$ & 0.05 & $-\mathbf{0 . 4 9}$ \\
Lengths of upper glume & $\mathbf{0 . 5 6}$ & $\mathbf{0 . 5 2}$ & 0.05 & $-\mathbf{0 . 4 4}$ \\
Lengths of lemma & $\mathbf{0 . 6 0}$ & $\mathbf{0 . 5 5}$ & -0.30 & 0.29 \\
Lengths of awn & 0.20 & 0.20 & $\mathbf{0 . 6 1}$ & -0.27 \\
Number of flowers per spikelet & -0.14 & $\mathbf{0 . 5 7}$ & $-\mathbf{0 . 6 4}$ & 0.34 \\
Number of ribs & $\mathbf{- 0 . 6 9}$ & 0.37 & $\mathbf{0 . 4 9}$ & -0.06 \\
Number of veins & $-\mathbf{0 . 6 3}$ & $\mathbf{0 . 4 6}$ & $\mathbf{0 . 4 9}$ & 0.18 \\
Number of sclerenchyma bundles & $\mathbf{0 . 6 7}$ & $\mathbf{0 . 4 9}$ & $\mathbf{0 . 4 1}$ & 0.02 \\
Number of seeds per plant & 0.33 & -0.22 & 0.37 & $\mathbf{0 . 5 6}$ \\
1000 seed weight & 0.01 & -0.17 & $\mathbf{0 . 4 3}$ & 0.18 \\
\hline
\end{tabular}

Note. Bold text indicates correlation $|r| \geq 0.4$.

PC3 and PC4 highlight relationships between seed production and other morpho-anatomical variables. Decreasing number of flowers is associated with longer awns and higher seed weight. Seed number per plant positively correlated with length and diameter of laminas but showed negative relationship with length of glumes.

We chose to show only most important first two PCA axes in Figure 1. A scatter plot revealed significantly greater variation in morpho-anatomical traits of $F$. rubra collection originating from Ukrainian populations than from Latvian ones. In addition, the majority of plants originated from Latvia's populations could be described as relatively smaller, with shorter, tougher leaf laminas and producing smaller seed number per plant. This could be explained by past climatic experience of plant ecotypes originating from southern part of $F$. rubra range. Malyshev et al. (2014) have showed that the faster growth rate of southern Arrhenatherum elatius (L.) P.Beauv. ex J.Presl et C.Presl ecotypes resulted in higher biomass accumulation.

It is well known that only the genotypes with a high seed production are promising for grass breeding
(Lemežienè et al., 2007). As a result, 16 populations ( 5 from Ukraine and 11 from Latvia) were eliminated and further analysis was carried out on the populations with an average seed number exceeding 280 per plant. The second PCA analysis was performed only on important pre-breeding traits (Fig. 2).

Forage and lawn grasses require different selection strategies (Feuerstein, 1994). In the experimental collection, the populations with Ukrainian origin (Nos. 7, 13 and 14) displayed high-grade lawn traits: had plant height less than $100 \mathrm{~cm}$ and small diameter of laminas. Plants suitable for forage production were chosen from the three populations originating from Ukraine (Nos. 6, 10 and 12) and one from Latvia (No. 26). They had quite high, long-leaved plants and in the PCA situated furthest along the first and second components in the diagram. Consequently, our results suggest that red fescue that originated from the southern part of its distribution range exhibited higher diversity of morpho-anatomical traits. This confirms a greater suitability of the populations from this region as a potential for collection of useful genes for F. rubra improvement in further breeding. 


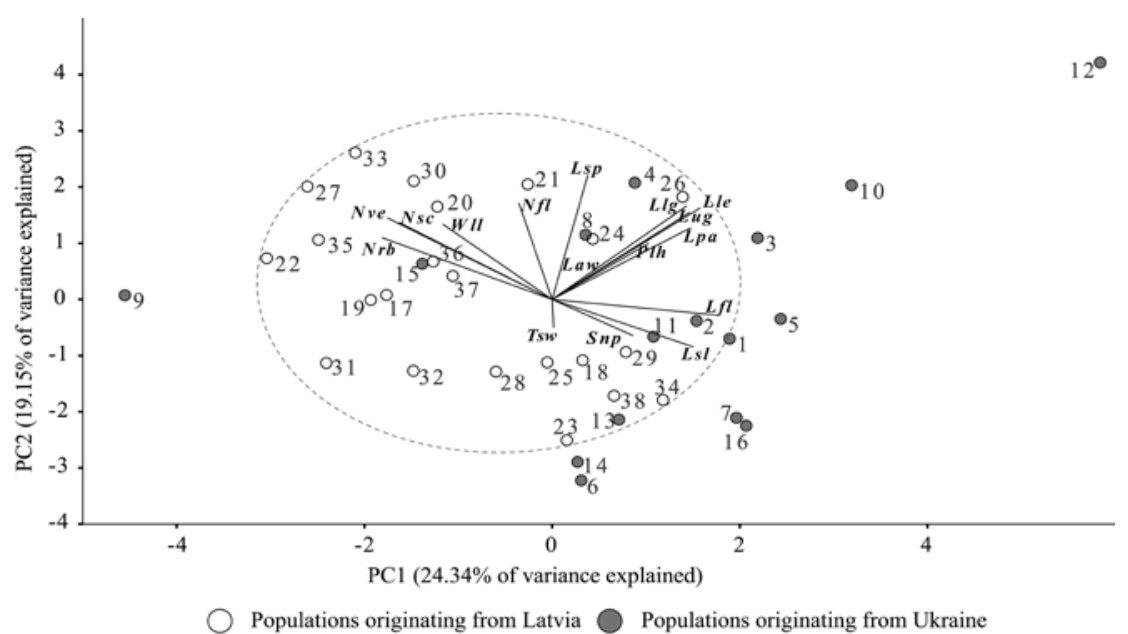

Notes. Length of: Lpa - panicle, Lfl, Lsl - flag, stem leaf lamina, Lsp - spikelet, Lug, Llg - upper, lower glume, Lle - lemma, Law - awn; number of: Nfl - flowers per spikelet, Nsc - sclerenchyma bundles, Nve - veins, Nrb - ribs; Wll - width of leaf lamina, $\mathrm{Plh}$ - plant height, Snp - seed number per plant, Tsw - 1000 seed weight. Population number as in Table 1. Dashed line is arbitrary outline covering all Latvian populations.

Figure 1. Principal component analysis of morpho-anatomical traits in Festuca rubra populations grown in the collection

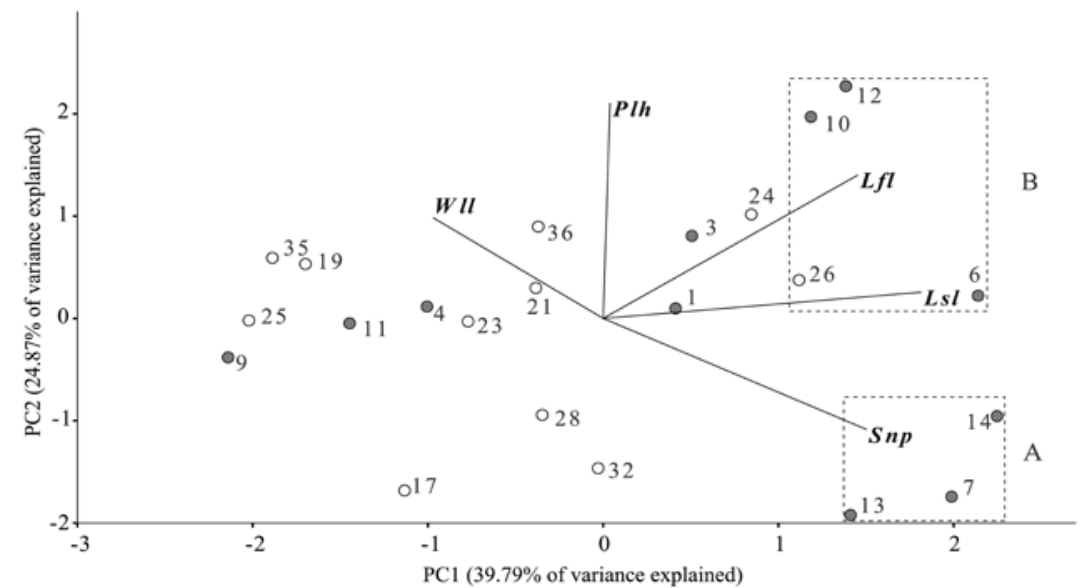

Notes. Snp - seed number per plant, Plh - plant height, Lfl, Lsl - length of flag, stem leaf lamina, Wll - width of leaf lamina. Population number as in Table 1. Dashed outline covers most promising lawn (A) or forage (B) type populations.

Figure 2. Principal component analysis of important pre-breeding morpho-anatomical traits in selected Festuca rubra collection populations

\section{Conclusions}

1. Southern latitudinal ecotypes of F. rubra compared to the northern ecotypes in average had longer leaves and produced more seeds when transferred to the north and grown in the cultural conditions.

2. Higher diversity in morpho-anatomical traits, discovered in Ukrainian F. rubra populations, confirms their great potential for collection of useful genes and ecological adaptations. Seven populations (4 forage and 3 lawn type) were selected for further breeding. Six of them originated from Ukrainian populations.

\section{Acknowledgments}

This work was part of ESF project "Scientific validation of C3 and C4 herbaceous plants' multifunctionality for innovative technologies: phyto raw materials - bio-products - environmental effects" (VP1-3.1-MM-08-K-01-023).

\section{References}

Altpeter F., Xu J. 2000. Rapid production of transgenic turfgrass (Festuca rubra L.) plants. Journal of plant physiology, 157 (4): 441-448 http://dx.doi.org/10.1016/S0176-1617(00)80029-2

Bertin C. A., Senesac A. F., Rossi F. S., DiTommaso A., Weston L. A. 2009. Evaluation of selected fine leaf fescue (Festuca) cultivars for turf quality and weed suppression. Horticulture Technology, 19: 660-668

Bonos S. A., Clarke B. B., Meyer W. A. 2006. Breeding for disease resistance in the major cool-season turfgrasses. Annual Review of Phytopathology, 44: 213-234 http://dx.doi.org/10.1146/annurev.phyto.44.070505.143338

Bu H., Chen X., Xu X., Liu K., Jia P., Du G. 2007. Seed mass and germination in an alpine meadow on the eastern Tsinghai-Tibet plateau. Plant Ecology, 191 (1): 127-149 http://dx.doi.org/10.1007/s11258-006-9221-5

Dabrowska A. 2011. Variability of morphological and anatomical traits in natural populations of Festuca rubra and F. nigrescens. Acta Agrobotanica, 64 (4): 159-170 http://dx.doi.org/10.5586/aa.2011.057 
Davies C. E., Moss D., Hill M. O. 2004. EUNIS habitat classification, revised 2004. European Environment Agency, European Topic Centre on Nature Protection and Biodiversity, $307 \mathrm{p}$.

Feuerstein U. 1994. Differences between forage grass and lawn grass breeding. Rognli O. A. et al. (eds.). Breeding fodder crops for marginal conditions: proceedings of the $18^{\text {th }}$ EUCARPIA Fodder Crops Section meeting. 2: 185-186 http://dx.doi.org/10.1007/978-94-011-0966-6_24

Guo H., Mazer S. J., Du G. 2010. Geographic variation in seed mass within and among nine species of Pedicularis (Orobanchaceae): effects of elevation, plant size and seed number per fruit. Journal of Ecology, 98 (5): 1232-1242 http://dx.doi.org/10.1111/j.1365-2745.2010.01688.x

Hammer Ø., Harper D. A. T., Ryan P. D. 2001. PAST: paleontological statistics software package for education and data analysis. Palaeontologia Electronica, 4 (1):1-9

Huyghe C. 2010. Grasslands and forage crops in Europe: context and stakes. Consequences for breeding. Biotechnology in Animal Husbandry 26 (spec. iss.): 1-18

Jackson D. A. 1993. Stopping rules in principal components analysis: a comparison of heuristical and statistical approaches. Ecology, 74: 2204-2214 http://dx.doi.org/10.2307/1939574

Kanapeckas J., Lemežienė N., Stukonis V., Kemešytė V., Konik G. S. 2010. Evaluation of morphological traits and biological characteristics of the wild Ukrainian ecotypes of Festuca species. Vagos, 86 (39): 7-12 (in Lithuanian)

Lemežienè N., Kanapeckas J. 2008. Selection efficiency of wild ecotypes for forage and turf grass breeding. Biologija, 54 (2): $125-128$ http://dx.doi.org/10.2478/v10054-008-0026-4

Lemežienė N., Kanapeckas J., Tarakanovas P. 2007. Evaluation of smooth-stalked meadow grass (Poa pratensis L.) genetic resources for breeding purposes. Biologija, 53 (3): 56-58
Ma H. Y., Liang Z. W., Wang Z. C., Chen Y., Huang L. H., Yang F. 2008. Lemmas and endosperms significantly inhibited germination of Leymus chinensis (Trin.) Tzvel. (Poaceae). Journal of Arid Environments, 72 (4): 573-578 http://dx.doi.org/10.1016/j.jaridenv.2007.06.013

Malyshev A. V., Henry H. A. L., Kreyling J. 2014. Relative effects of temperature $v s$. photoperiod on growth and cold acclimation of northern and southern ecotypes of the grass Arrhenatherum elatius. Environmental and Experimental Botany, 106: 189-196 http://dx.doi.org/10.1016/j.envexpbot.2014.02.007

Metzger M. J., Bunce R. G. H., Jongman R. H. G., Sayre R., Trabucco A., Zomer R. 2013. A high-resolution bioclimate map of the world: a unifying framework for global biodiversity research and monitoring. Global Ecology and Biogeography, 22: 630-638 http://dx.doi.org/10.1111/geb.12022

Rao K. M., Rognli O. A. 2014. Meadow fescue. Cai H. et al. (eds.). Genetics, genomics and breeding of forage crops, p. $90-108$

Stancík D. 2003. Las especies del género Festuca (Poaceae) en Colombia. Darwiniana, nueva serie, 41 (1-4): 93-153 (in Spanish)

Stanisavljević R., Djokić D., Milenković J., Terzić D., Stevović V., Tomić D., Dodig D. 2014. Drying of forage grass seed harvested at different maturity and its utility value in autumn and spring sowing time. ZemdirbysteAgriculture, 101 (2):

http://dx.doi.org/10.13080/z-a.2014.101.022

Tarakanovas P., Kanapeckas J. 2005. Evaluation of red fescue turfgrass accessions in genetic collection. Biologija, 4: $34-37$

ISSN 1392-3196 / e-ISSN 2335-8947

Zemdirbyste-Agriculture, vol. 102, No. 4 (2015), p. 437-442

DOI $10.13080 / \mathrm{z}-\mathrm{a} .2015 .102 .056$

\title{
Morfoanatominių požymių įvairovè skirtingos kilmès raudonojo eraičino (Festuca rubra L.) populiacijose
}

\author{
V. Stukonis ${ }^{1}$, S. Juzėnas ${ }^{2}$, J. Cesevičiené ${ }^{1}$, E. Norkevičienè ${ }^{1}$ \\ ${ }^{1}$ Lietuvos agrarinių ir miškų mokslų centro Žemdirbystės institutas \\ ${ }^{2}$ Vilniaus universitetas
}

\section{Santrauka}

Skirtingos kilmės Festuca rubra 38 laukinès populiacijos, surinktos skirtingose Ukrainos ir Latvijos bioklimatinėse zonose, tirtos Lietuvos agrarinių ir miškų mokslų centro Žemdirbystės institute. Tyrimo tikslas - nustatyti skirtingos kilmès F. rubra laukinių populiacijų morfoanatominių požymių įvairovę ir įvertinti jos ryši su populiacijų geografine kilme. Nustatyta, kad skirtingose arealo dalyse surinktų populiacijų daugumos požymių vidurkiai buvo panašūs, tačiau iš Ukrainos kilę F. rubra augalai buvo vidutiniškai aukštesni, pasižymèjo ilgesniais lapais ir subrandino daugiau sėklų. Tai sietina su pietinių platumų ekotipų geba prisitaikyti prie ilgesnio vegetacijos laikotarpio. Ukrainos populiacijose nustatytas didesnis $F$. rubra augalų morfologinių ir anatominių požymių įvairavimas rodo didesni jų potencialą naujų veislių selekcijai. Pagal žolių selekcijai vertingus morfologinius požymius išsiskyrė 7 populiacijos, iš kurių 6 buvo surinktos Ukrainoje ir 1 - Latvijoje.

Reikšminiai žodžiai: augalų selekcija, ekotipas, geografinè kilmė, sėklų derlius, veja. 